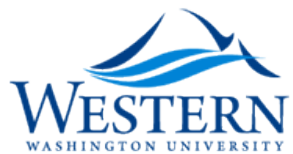

Western Washington University

Western CEDAR

$10-2008$

\title{
Priming Presidential Votes by Direct Democracy
}

Todd Donovan

Western Washington University, todd.donovan@wwu.edu

Caroline J. Tolbert

Daniel A. Smith

Follow this and additional works at: https://cedar.wwu.edu/politicalscience_facpubs

Part of the Political Science Commons

\section{Recommended Citation}

Donovan, Todd; Tolbert, Caroline J.; and Smith, Daniel A., "Priming Presidential Votes by Direct Democracy" (2008). Political Science Faculty Publications. 9.

https://cedar.wwu.edu/politicalscience_facpubs/9 


\section{CAMBRIDGE UNIVERSITY PRESS}

\section{Southern Political Science Association}

Priming Presidential Votes by Direct Democracy Author(s): Todd Donovan, Caroline J. Tolbert and Daniel A. Smith Source: The Journal of Politics, Vol. 70, No. 4 (Oct., 2008), pp. 1217-1231

Published by: Cambridge University Press on behalf of the Southern Political Science Association Stable URL: http://www.jstor.org/stable/30219495

Accessed: 23/10/2014 17:17

Your use of the JSTOR archive indicates your acceptance of the Terms \& Conditions of Use, available at http://www.jstor.org/page/info/about/policies/terms.jsp

JSTOR is a not-for-profit service that helps scholars, researchers, and students discover, use, and build upon a wide range of content in a trusted digital archive. We use information technology and tools to increase productivity and facilitate new forms of scholarship. For more information about JSTOR, please contact support@ jstor.org. 


\title{
Priming Presidential Votes by Direct Democracy
}

\author{
Todd Donovan Western Washington University \\ Caroline J. Tolbert University of lowa \\ Daniel A. Smith University of Florida
}

\begin{abstract}
We demonstrate that direct democracy can affect the issues voters consider when evaluating presidential candidates. Priming theory assumes that some voters have latent attitudes or predispositions that can be primed to affect evaluations of political candidates. We demonstrate that: (1) state ballot measures on same sex marriage increased the salience of marriage as an issue that voters used when evaluating presidential candidates in 2004, particularly those voters less interested in the campaign and those likely to be less attentive to the issue prior to the election; and (2) that the primed issue (gay marriage) was a more important factor affecting candidate choice in states where marriage was on the ballot.
\end{abstract}

S tudies of presidential elections have shifted from suggesting that campaigns have minimal effects (e.g., Berelson, Lazersfeld, and McPhee 1954; Campbell et al. 1960; Finkel 1993), toward a growing consensus that campaigns matter (e.g., Holbrook 1996; Johnston, Hagen, and Jamieson 2001; Shaw 1999). We contribute to the study of presidential elections by establishing that state-level institutions of direct democracy provide an avenue for agenda setting and priming. Scholars have identified that information about policy issues generated during campaigns affects the issues voters use when evaluating candidates (Johnston et al. 1992) and the weight they assign issues when voting (Druckman, Jacobs, and Ostermeier 2004). In this paper, we build on work by Nicholson (2005) to demonstrate that issue salience in a presidential election can be conditioned by referendums and initiatives appearing on state ballots. We also demonstrate that direct democracy can have potentially important effects on presidential vote choice. These findings are noteworthy because they link agenda setting and priming effects in a presidential contest to an institutional mechanism that campaigns may be able to control for strategic purposes.

Experimental and survey-based studies identifying campaign effects often emphasize the role of information generated by events largely beyond the control of candidates and campaigns. For example, sudden media attention to Iran's overture to nego- tiate with President Carter in the waning days of the 1980 campaign may have doomed Carter's reelection prospects by refocusing public attention on the hostage crisis (Ansolabehere, Behr, and Iygengar 1993: 176; Iyengar and Kinder 1987). Likewise, revelations of the Iran-Contra scandal in late November 1986 led to heightened media attention to Nicaragua. Survey research demonstrates that this caused citizens to evaluate President Reagan more negatively as they assigned greater weight to his relatively unpopular Central America policy (Krosnick and Kinder 1990). A spike in news coverage of the 1991 Gulf War increased the influence of assessments of George H.W. Bush's handling of the war on his job approval and reduced public attentiveness to other policy issues (Krosnick and Brannon 1993), but when media attention returned to domestic economic issues approval of Bush deteriorated.

Of course, campaigns involve attempts at identifying and promoting issues that will cast a candidate in a favorable light, and/or an opponent in negative terms (Geer 1996; Druckman, Jacobs, and Ostermeier 2004). Avenues for this include strategic use of imagery (Popkin 1991), rallies, speeches, paid advertising (Jamieson 1996), press releases, and debates (Lanoue 1992). The potential for these efforts to achieve their strategic goals likely depends on many factors; including (but not limited to) how, if, or when themes from the campaign are reported in the media, whether voters are exposed to the information 
in a manner consistent with the goal of the campaign, and whether or not the information is disseminated at the optimal place and time. Campaigns seeking to promote a particular issue face two dilemmas: damaging events exogenous to a campaign's strategy may emerge and shift the agenda unfavorably, and strategic attempts at promoting a specific issue depend on how compliant the news media is.

We suggest that use of state-level referenda and initiatives can serve as another avenue that a campaign (or surrogate actors sympathetic to a campaign) may use to affect the issues voters apply to candidate assessments. The institutions of state-level direct democracy (initiative and referendum) may act as a tool that increases how much voters consider a particular issue at the time they are making their choice for president (Nicholson 2005). We assess this in the context of the 2004 presidential election. In that year, social conservative activists and state legislators placed questions proposing a ban on "same-sex" marriage on the ballot in 13 states. $^{1}$ Seven were placed on state ballots by state legislatures, six by citizen-group petition efforts. ${ }^{2}$ Every measure passed, receiving $70 \%$ support on average. The 2004 election provides an excellent case for studying if direct democracy conditioned how voters applied a relatively low-salience valence issue to their evaluations of two candidates who held distinct positions on the issue. ${ }^{3}$ We propose that statewide votes on same-sex marriage created an information environment that increased the likelihood that some voters used the gay marriage issue when evaluating the presidential candidates and voting.

\section{State-Level Direct Democracy and Issues in National Elections}

At present, scholars know relatively little about how state-level ballot measures affect the issues voters

${ }^{1}$ Technically, the measures would define marriage as being between a man and woman only.

${ }^{2}$ The marriage measure states were Arkansas, Georgia, Kentucky, Louisiana, Michigan, Mississippi, Missouri, Montana, North Dakota, Ohio, Oklahoma, Oregon, and Utah. Arkansas, Michigan, Missouri, Ohio, and Oregon were considered competitive states early in the campaign. Louisiana and Missouri placed their measures as referendums on late-season primary ballots.

${ }^{3}$ John Kerry acknowledges he opposed a Constitutional ban on same-sex marriage and supported "civil unions" (Boston Globe February 24 2004). George W. Bush promoted the Constitutional ban and opposed civil unions. The August 2004 Pew survey found $60 \%$ opposed to "allowing gays and lesbians to marry legally" and $29 \%$ in favor. consider when evaluating presidential candidates. Candidates and parties have used ballot measures as "wedge" issues in attempts to divide a rival party's base of supporters (e.g., California's anti-illegal immigrant Proposition 187 and anti-affirmative action initiatives, see Nicholson 2005 Chapter 6; Bowler, Nicholson, and Segura 2006; Chavez 1998). Prominent state-level measures such as California's Proposition 13 property tax-cut of June 1978, and Missouri's 2006 stem cell vote, have affected political discourse beyond their respective states. Research also finds that cues from political elites shape opinions about ballot measures (Lupia 1994).

Nicholson (2005) provides the most systematic demonstration that opinions about issues on state ballots may, at times, shape evaluations of candidates. This can have national implications when a single ballot issue with a nominally coordinated national campaign appears simultaneously on many statewide ballots. Nicholson shows that ballot measures can have broad, national effects on electoral politics by affecting the issues (e.g., Nuclear Freeze in 1982) voters use when evaluating state and congressional candidates-even if candidates themselves avoid overt discussions of issues. Nicholson found that ballot propositions have the potential to prime voters' evaluations of gubernatorial and congressional candidates across multiple states, and that California initiatives may prime presidential votes in that state, but he does not model the national effects of ballot measures in presidential elections.

\section{A Theory of Agenda Setting and Priming via Direct Democracy}

Nicholson argues that an issue put forth as a ballot proposition can shape the political agenda by influencing the issues that voters consider and then implicitly "prime voters to evaluate candidates" $(2005,15)$ using the issue. There is some lack of clarity through the academic literature in how "agenda setting," "priming," and related concepts are defined and measured. ${ }^{4}$ We adopt the Ansolabehere, Behr, and Iygengar $(1993,148)$ definition of agenda setting as the effect of events and information on the importance voters accord an issue and adopt their conception of priming as an extension of agenda setting - a form of (indirect) persuasion that involves the isolation of a particular issue for use

${ }^{4}$ In addition to occasional overlap in use of these terms, related concepts include "issue framing" (Druckman 2004, 672). 
in evaluating politicians $(1993,176)$. The logic of priming effects in campaigns derives, in part, from theories of choice that treat the recall of considerations from memory as a rather passive process. As Mendelberg notes in a study of the priming of negative racial predispositions, "priming occurs when a person makes greater use of a given predisposition after exposure to communication that cues it in some way" (2001, 120). These models (e.g., Krosnick and Kinder 1990; Iyengar and Kinder 1987; Krosnick and Brannon 1983) and others assume that voters make decisions on the basis of bits and pieces of "information, prototypes, symbols, slogans and prejudices" (Bartels 2003, 50), and "considerations that are immediately salient" (Zaller 1992, 49). If events bring increased attention to a predisposition about an issue that voters have stored in memory, then voters may be primed, if even unconsciously, to become more likely to consider that issue when evaluating candidates. $^{5}$

Studies of priming often attribute heightened issue salience to the effects of mass media (e.g., Iyengar and Kinder 1987; chap. 7). This begs the question of how actual campaign events affect the content of news coverage, and hence, public attention to an issue. Mendelberg $(2001,4)$ provides examples of such mechanisms, noting that the campaign messages of Barry Goldwater (1964), Richard Nixon (1968), and others conveyed implicitly racial appeals that primed white voters' racial predispositions. Mendelberg shows the power Willie Horton had on generating media coverage that primed voters to apply racial resentment when evaluating Michael Dukakis in 1988. Nicholson $(2005,34)$ proposes that direct democracy is also a mechanism that can alter the set of issues voters consider to be importantparticularly when morality issues are proposed for public votes. We contend that state-level ballot measures act as a mechanism that affects the salience of an issue by increasing the amount of public attention directed at an issue and the timing of that attention.

Downs (1972) describes an issue-attention cycle where the duration of public attention to an issue often moves from an initial "preproblem stage" where mainly elites and attentive groups may be alarmed by a problem, through an "alarmed discovery" stage where mass attention increases, to a

\footnotetext{
${ }^{5}$ We make no assumptions about whether negative primes or negative predispositions are necessary or sufficient for priming. Our results, and those of Mendelberg (2001), demonstrate instances where the prime applies to latent negative predispositions about minority groups.
}

subsequent gradual decline in attention. We suggest that initiative and referendum campaigns associated with an issue provide a device to alter or extend the issue-attention cycle. Media attention associated with legislative placement of referendums banning samesex marriage on state ballots, state-level petition drives to qualify ballot initiatives, and campaign discourse associated with the issue may have generated more attention to gay marriage in these states than elsewhere, increasing the likelihood that voters recalled gay marriage from memory when they were evaluating presidential candidates, and thus increasing the likelihood that voters applied the issue to their candidate choice. By synchronizing the timing of the ballot measure campaigns with the presidential campaigns, direct democracy may cause attention to an issue to peak when voters are evaluating presidential candidates.

\section{Gay Marriage and the 2004 Presidential Election}

Issues associated with gay and lesbian rights have been a recurring feature in state and local politics (Haider-Markel and Meier 1996; Haider-Markel, Querze, and Lindaman 2007), but a series of events caused gay marriage to emerge rather suddenly as a national issue in the early stages of the 2004 campaign. Prior to 2004, state court cases had brought some attention to the issue. In his January 20, 2004 State of the Union speech, President George W. Bush mentioned the prospect of a federal constitutional amendment banning same sex marriage if "judges insist on forcing their arbitrary will on the people." On February 6, the Massachusetts Supreme Judicial Court issued an advisory opinion stating that a proposed civil union bill was unconstitutional because it denied gay couples equal access to marriage. On February 9, San Francisco Mayor Gavin Newsom announced he wanted to explore how the city could allow same sex couples to wed. Two days later, Bush announced his endorsement of a constitutional amendment to prohibit same-sex marriages and called for a congressional vote on the matter. Newsom focused even greater attention on the issue the next day (February 12) when he authorized samesex weddings in San Francisco. Weddings continued in the city until blocked by a California court four weeks later. Multnomah County (Portland) Oregon followed San Francisco and began performing samesex marriages on March 3, with the Oregon weddings continuing until April 20. Efforts to qualify state 
constitutional amendments were also launched in dozens of states during this period.

Nationally, media attention to gay marriage peaked in late February in response to these events, then declined through the summer, and peaked again in late October with a focus on state marriage measures. ${ }^{6}$ Voters generally tend to be more aware of ballot questions about morality issues than other ballot measures, particularly those questions that attract media attention (Nicholson 2003). We assess one aspect of media attention to gay marriage by examining the frequency that "gay marriage" was mentioned by newspapers in states where gay marriage was on the November ballot, and by comparable papers from states where marriage was not on the ballot. Full details of our case selection method, and more refined, color graphic illustrations of trends in press attention to gay marriage, are available online, in the appendix. ${ }^{7}$

Figure 1 plots the frequency that gay marriage was mentioned in several newspapers from states where the issue was before the voters, and Figure 2 plots the same trends for several comparable papers from states where it was not on the ballot. Trends illustrate the proportion of all stories about gay marriage from January through the end of October that occurred in each two week period. In both figures there is a peak in early March, when national media attention to the issue spiked as same-sex weddings occurred in San Francisco and Portland. The figures illustrate that press coverage of gay marriage in both sets of states was at a relative low point by early August (compared to late February and early March). However, in states where marriage was on the November ballot, in most newspapers the frequency that gay marriage was mentioned peaked again in October relative to where it was in February and March. In 14 of 16 papers from states where marriage was not on the ballot, we find relatively lower levels of attention to gay marriage in late October compared to February (two exceptions being Denver and St. Petersburg, FL). This second peak in press attention to gay marriage in states where it was on the ballot reflects a different information environment in those states, one we assume was associated with state-level marriage campaigns. Although many of the state marriage campaigns were low-budget affairs, Bush and Kerry's

\footnotetext{
${ }^{6}$ Evidence of this can be seen in a Goolge Trends search of news references to the term "gay marriage" in 2004. We thank an anonymous reviewer for introducing us to Google Trends. A graph of these trends is archived in Appendix B at the online appendix at http://journalofpolitics.org.

${ }^{7}$ Additional graphs are available at the online appendix.
}

positions on the issue were made clear by marriage campaigns and media attention (Campbell and Monson N.d.). Well-placed Bush campaign officials in states with marriage measures also worked to link Kerry to the unpopular position of supporting gay marriage. ${ }^{8}$

Extant research making use of opinion data have found that, nationally, opposition to gay marriage was associated with support for Bush (Hillygus and Shields 2005; Lewis 2005), and that some voters in states with marriage bans were more likely to support Bush (Campbell and Monson, N.d.). However, these studies do not examine how different state electoral contexts affected the salience and priming effects of gay marriage. ${ }^{9}$ In the analysis below, we examine survey data from early August and from the second half of October to test if respondents in states with marriage measures assigned greater importance to the gay marriage issue toward the end of the campaign, and if voters in those states were primed to apply gay marriage when voting for president.

Given the marriage campaigns and associated discourse and media attention where they occurred, gay marriage had the potential to be an issue for voters to use when evaluating the presidential candidates. Indeed there is evidence of public awareness of the marriage measures. Public opinion data collected by the Pew Foundation in the second half of October ${ }^{10}$ found that $42 \%$ of respondents in a national sample reported being aware of initiative, referendums, or constitutional amendments that would appear on their state ballot. Forty-five percent of respondents in states where marriage measures qualified mentioned gay marriage when asked an open-ended question about which measures were on their ballot.

${ }^{8}$ Examples of campaign efforts to distinguish between Bush and Kerry on the basis of marriage are in Appendix C. A Pew survey from mid 2004 found just $29 \%$ support for "allowing gays and lesbians to marry legally."

${ }^{9}$ These studies use quite different methods, and reach different conclusions about the importance of gay marriage in 2004 . Hillygus and Shields (2005) used postelection data to model the effects of attitudes about a U.S. constitutional amendment on vote choice. Their models do not directly compare the effect of residence in a ban state to residence in all other states. Lewis (2005) employs survey data from early in the campaign (March 2004) and does not account for the state a respondent lived in. Campbell and Monson (N.d.) and Mulligan (2008) estimate models that do allow for direct comparisons of the effect of residing in a state with a marriage ban versus residing elsewhere, and the former have no measures of attitudes about gay marriage.

${ }^{10}$ The national random sample telephone Mid October Political Survey was conducted for Pew by the Princeton Research Associates between October 15 and 19 and included 1,307 registered voters from the continental United States. Available: http://www.people-press.org. 
FIGURE 1 Proportion of total newspaper attention to gay marriage from January 1, 2004 - October 31, 2004 in states with marriage measures on the ballot.

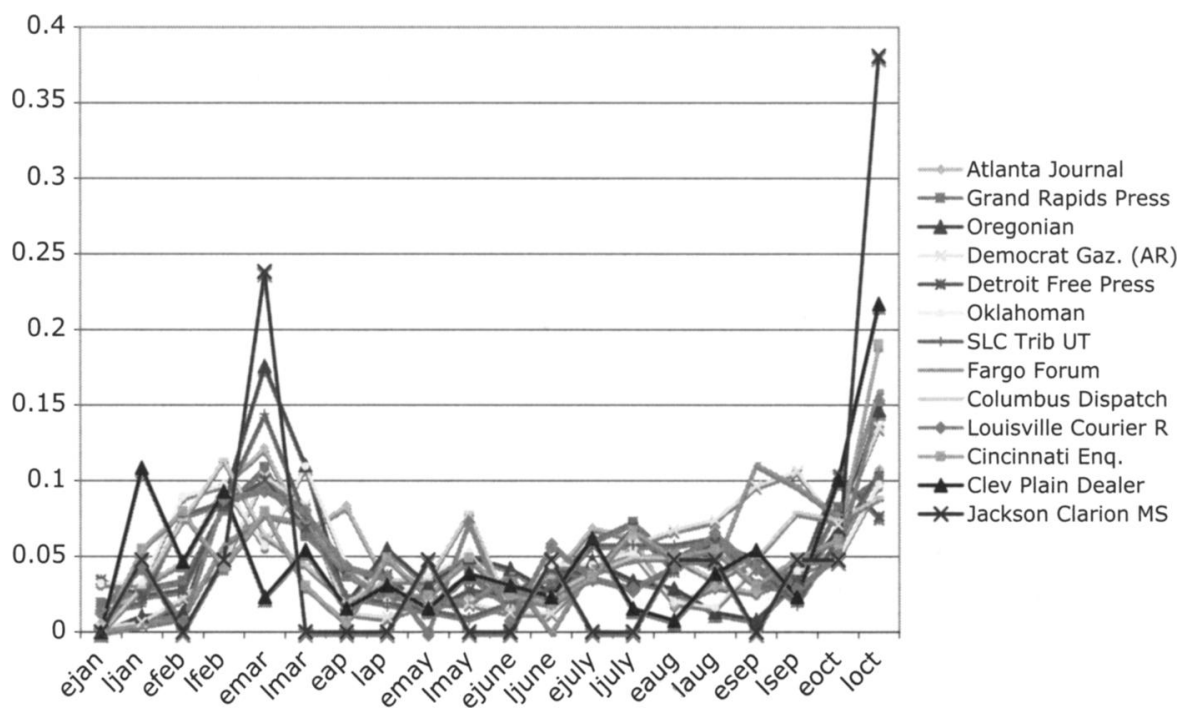

\section{Hypotheses}

We expect gay marriage had an agenda-setting effect that caused people in states with marriage measures to be more likely to consider gay marriage when assessing presidential candidates. We also expect that the potential for the effect was conditional on how receptive a person was to being primed to consider gay marriage. Studies of priming effects suggest that people knowledgeable about (or "experts" on) an issue may be the least receptive to a prime, in part because they have sufficient preexisting awareness to be immune to the prime. Empirical evidence of this is inconsistent (Krosnick and Brannon 1993, 965). However, framing effects-a related concept-have also been shown to be conditional-that is, there are demonstrated limits to framing effects (Druckman 2001). Kinder and Sanders (1990) demonstrate that better-informed people were less susceptible to the framing of affirmative action, and Haider-Markel and Joslyn (2001) find similar effects with gun control. Priming theory assumes people have a range of considerations stored in memory that might be used when making decisions (Zaller 1992) and that they make choices based on the information most readily available. A prime can increase the likelihood that a particular piece of information in memory is used.

We suggest those having greater focus on the issue being primed, and those more attentive to issues generally, may be less receptive to the prime. This is similar to Converse's point $(1962,589)$ that people who consume the most political information may be least likely to have their attitudes affected by addi- tional information (see also McGuire 1968). Put differently, some voters may have readily accessible concerns about gay marriage such that the issue need not be primed in order for it to enter into their range of considerations. Others, who may have latent predispositions but who are not focused on the issue, may be more likely to be primed to consider the issue when evaluating candidates. In this case, born again or fundamentalist Christians may have already have a higher level of concern about gay marriage (Olson, Cadge, and Harrison 2006) regardless of the campaign context they resided in, leaving them less receptive to the agenda setting effects of same sex marriage measures. We also expect voters who are most attentive to a campaign to be more attentive to issues generally, so when a ballot measure focuses attention on any specific issue their propensity to consider that issue is less likely to be affected (compared to less interested people). We expect these people may also be less affected by additional information about the issue because their concerns about the issue may be more immediate (rather than latent) and already accessible.

Of course marriage measures may have reached state ballots because people in those states were predisposed to consider gay marriage, and to support President Bush. We test for this endogeneity (see Nicholson 2005, 39-40) by examining if people in states with marriage measures were already more concerned about gay marriage early in the campaign season. If the ballot measures primed the marriage issue, attitudes measured before the campaign season should show no relationship between saying that gay 
Figure 2 Proportion of total newspaper attention to gay marriage from January 1, 2004 - October 31, 2004 in states without marriage measures on the ballot.

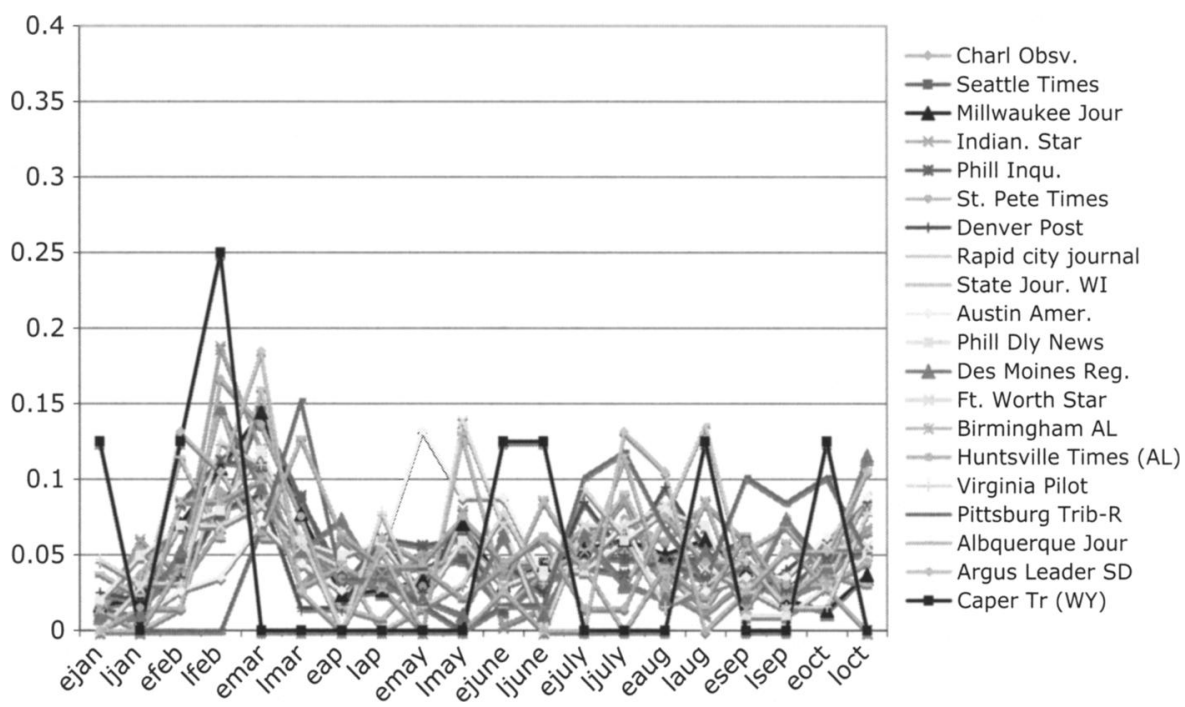

marriage was very important, and residence in a state where marriage was on the ballot-but we should see this relationship late in the season if the ballot measures prompted people to consider gay marriage when evaluating candidates. We also expect that the marriage measures primed voters in those states to link their concerns about gay marriage to their choice for president.

\section{Data and Measures}

We test our hypotheses with data from three national polls conducted in 2004 by Pew Research Center: an early August 2004 survey, ${ }^{11}$ a mid-October survey, ${ }^{12}$ and with a pre/postelection panel survey. ${ }^{13}$ By comparing results across the August and October samples, we can test if residents in states with marriage on the ballot were simply predisposed to be concerned about gay marriage or if ballot measures had agendasetting effects. The November postelection survey

\footnotetext{
${ }^{11}$ Pew Nationally representative sample of 1,512 adults living in the continental United States. Telephone interviews conducted by the Princeton Data Source from August 5 to 10, 2004. Available: http://www.people-press.org.

${ }^{12}$ See note 10 above.

${ }^{13}$ The Pew Post Election Callback Survey used telephone reinterviews conducted November 5-8, 2004 among 1,209 voters who had been contacted in one of two October Pew surveys (both random, national telephone surveys). See Appendix D at the online appendix.
}

included a panel of respondents from the October sample and is used as robustness check.

The Pew early August and mid-October preelection surveys included an identical battery of questions asking voters how concerned they were about a fixed list of 16 issues when considering the presidential candidates. Respondents were asked, "In making your decision about who to vote for in the presidential election, how important will the issue of \{\} be?" with the 16 issues rotated randomly. In each period, terrorism, the economy, Iraq, jobs, and education ranked highest nationally. Gay marriage ranked as one of the least-mentioned issues in each period, yet one-third of respondents did indicate that the issue was "very important." A simple cross tabulation of the August data comparing responses from the 13 states where marriage measures would be voted on, to responses from other states, demonstrates there was no significant difference in perceptions of the importance of gay marriage across the two groups (Chi Square $=0.33, \mathrm{p}=.56$ ).

We suggest that measuring attitudes about gay marriage in terms of those who felt it was a "very important" issue captures the salience of the issue and provides a valid surrogate measure of opposition to gay marriage. As evidence of this, the August survey asked the policy issue concern question cited above, as well as a specific question about supporting or opposing gay marriage. In that survey, we find that $81 \%$ of respondents who said that gay marriage was a "very important" issue also opposed gay marriage. In other words, there is a strong relationship between 
salience, as measured by the Pew gay marriage issue concern question, and valence. The mid-October Pew survey lacks a specific question about opposition to gay marriage, but the August data provide strong evidence that people very concerned about gay marriage were overwhelmingly opposed to gay marriage.

\section{Testing for Agenda Setting and Issue Priming}

In Table 1 we report logistic regression models that estimate if an individual reported being "very concerned" about gay marriage when evaluating presidential candidates in August and October, respectively. Respondents indicating that the gay marriage issue was "very important" are coded 1, and those indicating the issue was only "somewhat important," "not too important," or "not at all important" are coded $0 .{ }^{14}$

Since we assume that concerns about gay marriage are accentuated by campaigns associated with same sex marriage measures, one primary explanatory variable is the presence or absence of a marriage measure in a respondent's state. This is represented with a dummy variable identifying residence in states where marriage was on the ballot. We expect residence in a ban state to have more of an effect on concern about gay marriage in mid October, than in early August when there was less attention to the issue (See Figure 1).

Models testing for this agenda-setting effect also include several necessary control variables. Given findings that Protestants and Republicans are less supportive of ballot measures extending rights to gays and lesbians (Loftus 2001), and Protestants are less supportive of same sex marriage (Olson, Cadge, and Harrison 2006), we account for religion with a dummy variable representing self-identified Protestants. As a more restrictive test, we also estimate models with religion measured by a question asking respondents if they described themselves as "born again, evangelical Christian, or fundamentalist Christian." 15 Partisanship is represented with two dummies for Republicans and Democrats, respectively,

\footnotetext{
${ }^{14} \mathrm{Few}$ people said that any given issue was not at all important, or not very important. The meaningful variation on the Pew questions about issue importance is between saying an issue was "very important," or otherwise. Thus, we collapse the issue importance variable into a binary measure.

${ }^{15}$ See coding details in Appendix $\mathrm{E}$ at the online appendix.
}

with independents serving as the reference group. ${ }^{i o}$ Past studies establish that education is associated with support for civil liberties for gays and lesbians (Loftus 2001; Sniderman, Brody, and Tetlock 1991). Studies of opinions about homosexuality have also found that heterosexual men and women reason differently about gays and lesbians, respectively, with men less likely than women to support recognition of samesex relationships (Herek 2002). Women are also less likely than men to condemn homosexuality on morality grounds, while blacks may be more likely than whites to do so (Loftus 2001: 772-3). Thus, our models also control for education (an ordinal scale), gender $(1=$ female, $0=$ male $)$, race/ethnicity $(1=$ white, $0=$ other), as well as age (in years) and income (an ordinal scale). ${ }^{17}$

Estimates of presidential vote choice also control for the importance of major issues that voters may have used when evaluating the 2004 presidential candidates, including concerns about terrorism, the economy, and the Iraq War. ${ }^{18}$ Finally, all models reported below are estimated by clustering respondents by state to adjust the standard errors for the multilevel data, as well as using robust (HuberWhite) standard errors. ${ }^{19}$

\section{Direct Democracy Agenda Setting}

Table 1 presents the results of three models estimating the importance voters accorded gay marriage when evaluating presidential candidates in 2004. Each model is first estimated with data from the early

\footnotetext{
${ }^{16}$ Alternate models estimates with a 7 -point scale produce the same substantive conclusions. See Appendix Table A4 at the online appendix.

${ }^{17}$ See coding details in Appendix $\mathrm{E}$ at the online appendix.

${ }^{18}$ These were measured in the same fixed list of (rotated) questions about issues important in evaluating presidential candidates that also included the gay marriage question.

${ }^{19}$ We estimated our models with other controls for state-level factors associated with the occurrence of gay marriage measures, including Bush's 2000 vote share in a state, Bush's 2004 vote share, state-level measures of attitudes about homosexuality (from Brace et al. 2002), a dummy variable representing initiative states, and an instrument that predicted the probability of a state having a gay marriage proposition estimated by a logistic regression equation accounting for the presence of a state initiative process and the state's support for Bush. Apart from a loss of cases associated with the Brace et al. measure, the substantive results reported here are similar when these controls added to these models. The instruments and the binary variable for initiative state were not significant, whereas measures of Bush vote were.
} 


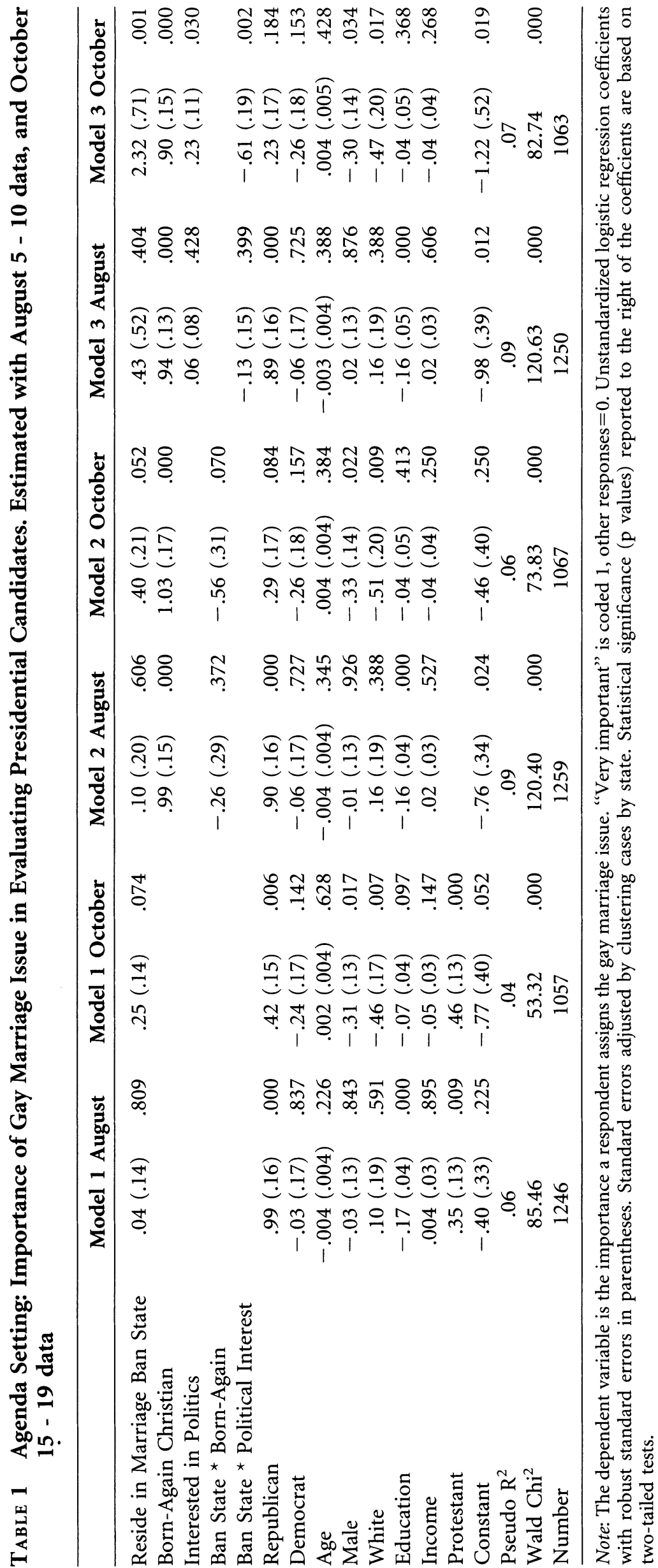


August Pew survey and then with data from the midOctober Pew survey. We expect to find an agendasetting effect in surveys conducted in ban states in conjunction with the October spike in attention to gay marriage. Prior to the campaign (early August) we expect less difference in issue salience associated with residence in a state with a marriage ban measure.

Estimates in Table 1 are consistent with these expectations. Model 1 (in Column 1) demonstrates that in August there was no relationship between residing in marriage vote state and believing the issue of gay marriage was very important for evaluating presidential candidates. When Model 1 is estimated using survey data from mid-October (in Column 2), we find that respondents in states where gay marriage was on the ballot were significantly more likely to say gay marriage was very important in their consideration of presidential candidates. As an additional check for endogeneity, we also use Model 1 to estimate if residence in marriage ban states was associated with increased likelihood saying "moral values" were very important issues (see Appendix Table A2). Respondents in states with marriage on the ballot were no more likely to cite moral values as very important in August or October, yet they did become more likely to rank gay marriage as very important by mid-October. This is consistent with the idea that state campaigns about marriagerather than something else unique to these statesincreased the salience of gay marriage as an issue for evaluating presidential candidates.

As expected, partisanship, religion, education, race, and gender also affect the likelihood that a respondent said the issue was very important. In each time period, Republicans, Protestants, and those with less education were significantly more likely, respectively, to say that gay marriage was a very important issue for them when evaluating the presidential candidates. Nonwhites and women were more concerned about gay marriage in October, but not in August. These data suggest that near the end of the campaign, same-sex marriage ballot measures heightened the salience of gay marriage for some voters in states where the issue was on the ballot.

We noted above that the agenda-setting effects of the marriage measures could affect those who were less attentive to the campaign generally and to gay marriage specifically. Estimates reported in Table 1 demonstrate that people who identified themselves as "born again," "Evangelical" or "Fundamentalist" Christians were significantly more likely to mention that gay marriage was a very important issue, regardless of the time or place they were surveyed. ${ }^{2 \hat{v}}$ Model 2 tests if the agenda-setting effect of these ballot measures was conditional (Jaccard, Turrisi, and Wan 1990, 26-27) on whether a respondent was a born again Christian or not; Model 3 tests if the agenda-setting effect was conditional on (low) selfreported interest ${ }^{21}$ in the presidential campaign. In Model 2, the main coefficient for residence in a state with marriage on the ballot reflects the conditional effect of being in a ban state for a person who is not a born again Christian. In Model 3, the main coefficient for residence in a marriage vote state reflects the conditional effect of levels of interest in the election. The substantive meaning of the estimates from Table 1 are better understood when presented as probability simulations. Clarify simulations where other variables are set to their mean/modal values are reported in Table 2 .

In the August estimation of Model 2, neither the interaction term nor the coefficient for residence in a marriage ban state are statistically significant. That is in August, nonborn again Christians were no more likely to believe gay marriage was an important issue in the election, regardless of where they lived. Later in October, however, we find that non-born again / non-fundamentalist respondents were more likely to believe gay marriage was an important issue in the presidential election if they lived in a state with a marriage ban measure, as evident by the base term for residence in a state with a vote on marriage. We find a similar effect with the interaction between interest and residence in a state with a marriage measure (Model 3).

Non-born again respondents are estimated to have a .09 increased probability of rating gay marriage as a very important issue if they lived in a state where marriage was placed on the ballot. The effects of political interest illustrated in Table 2 are striking. People reporting "quite a lot" of interest in the presidential campaign are estimated to have roughly the same low probability of saying that gay marriage was an important issue, regardless of whether they were exposed to a same sex marriage campaign. It is important to note that $70 \%$ of respondents reported this level of interest in October. However, the minority who reported less interest in the campaign were much more likely to mention gay marriage as an issue to evaluate candidates if they lived in a state

\footnotetext{
${ }^{20}$ This is seen in Model 3 (Table 1)

${ }^{21}$ Respondents were asked, "How much thought have you given to the upcoming presidential election? Values are coded as quite a lot (3), some (2), only a little (1), and none (0).
} 
where attention to the gay marriage question was heightened by a same sex marriage measure.

\section{Gay Marriage and Presidential Vote Choice}

Thus far we have demonstrated agenda-setting effects of state level marriage measures in the presidential election. There were similar trajectories of press attention to gay marriage in metropolitan newspapers through the summer of 2004, with press attention to gay marriage then rising more in October in states where marriage was on the ballot. Table 1 that demonstrates that respondents in states with marriage on the ballot-rated gay marriage as "very important" in October (but not August).

But did the salience of gay marriage affect how people in states with marriage ban measures voted? That is, did residence in a marriage ban state increase the likelihood that voters focused on the gay marriage issue when choosing between candidates? Recall that our measure of the importance voters assigned gay marriage taps both the salience and valence of the issue; those saying gay marriage was a very important issue were overwhelmingly opposed to gay marriage. Given that Bush's opposition to gay marriage was explicit and well publicized, and given our issue importance measure captures opposition to gay marriage, it is not surprising that people who reported being very concerned about gay marriage were more likely to vote for Bush in 2004. This can be seen in Column 1 of Table 3.

In order to test if marriage ballot measures primed voters to have an increased likelihood of voting Bush, we estimate models of vote choice that include an interaction between residence in a ban state and rating gay marriage as a very important issue. The coefficients for the original dummy variable components of this interaction (columns 2, 3, and 4 in Table 3) represent conditional effects. That is, the estimate for "resides in gay marriage ban state" reflects the effect of that variable if a respondent reported that gay marriage was not very important. The estimate for "gay marriage issue very important" reflects the effect of that variable for people who do not live in ban states.

Estimates of these models are reported in Table 3. The dependent variable is coded 1 if the respondent reported an intention to vote Bush, 0 if Kerry or other. Models reported in the first three columns are estimated with October (preelection) data, the final column replicates the priming model with data from November. Column 1 reports the estimate of Bush vote without the priming interaction and shows people concerned with gay marriage were more likely to vote Bush, other things equal. Columns 2, 3, and 4 include the interaction term and show that under various specifications, the importance of gay marriage on Bush support is contingent upon whether a person lived in a state with marriage on the ballot. ${ }^{22}$ The model in Column 4 replicates Column 3 by estimating the respondent's reported vote with their preelection report of the importance of the gay marriage issue. With alternative specifications of these models employing different controls for religion (Table 3) and endogeneity (reported in Appendix Table A3), we consistently find a significant relationship between support for Bush and the interaction of assessments of gay marriage and residence in a marriage ban state. ${ }^{23}$ The effect of the salience of gay marriage on presidential voting is magnified among respondents who lived where there was a statewide same-sex marriage campaign. We find the same effect (reported in Appendix Table A4) when models in Table 3 are estimated with one subsample of respondents from states with marriage measures and one subsample of other respondents. There is a significant, positive relationship between ranking gay marriage as important and Bush vote among people in the marriage vote state subsample, but no significant relationship among people in the other group.

Beyond the priming effect of these campaigns, there could be something distinctive about people in the set of states where these ballot measures appeared; something that might increase observed consistency between issue concerns and vote choice across all manner of issues, including "moral" issues generally. Table 4 replicates the priming model reported in Table 3 (Column 3) with terms that represent the interaction between residence in a marriage ban state and whether respondents rated terrorism, Iraq, the economy, or "moral values" as very important issues, respectively. Results in Table 4 demonstrate that none of these counterfactual interaction effects are significant. Although each issue had significant effects on vote choice, "moral values" and other issues had no more (nor less) effect on support for Bush among people residing in states where marriage was on the

\footnotetext{
${ }^{22} \mathrm{~A}$ comparison of results between Column 2 and Column 3 also demonstrates that the priming effect, as represented by the interaction, holds whether we measure religion as "Protestant" or as "born again / Evangelical / Fundamentalist / Christian."

${ }^{23}$ We do not find this effect when these models are replicated with data from August.
} 


\section{TABle 2 Predicted Probabilities of Rating Gay Marriage as a Very Important Issue in Evaluating Presidential Candidates, October 2004}

\begin{tabular}{lcc}
\hline & Reside in Marriage Ban State & Reside in Other State \\
\hline $\begin{array}{l}\text { Religion } \\
\text { Born-again / Evangelical / }\end{array}$ & $.43(.04)$ & $.46(.03)$ \\
$\quad$ Fundamentalist Christian & $.32(.03)$ & $.23(.02)$ \\
Non Born-again / Evangelical / & & \\
$\quad$ Fundamentalist Christian & & $.25(.04)$ \\
Interest in campaign & $.27(.03)$ & $.23(.03)$ \\
Quite a lot & $.32(.05)$ & $.19(.04)$ \\
Some & $.41(.06)$ & $.16(.04)$ \\
Little & $.50(.10)$ & $.04)$ \\
None & &
\end{tabular}

Note: Estimated with Clarify from models in Table 1. Explanatory variables set at mean/modal values. Standard errors in parentheses.

ballot. Gay marriage, in contrast, did have a greater effect on Bush support in states where marriage was on the ballot.

The October Pew survey found $78 \%$ citing the economy as a very important issue for evaluating the candidates, $77 \%$ citing terrorism, $74 \%$ Iraq, compared to $32 \%$ citing gay marriage. By this measure, gay marriage was less important than other issues in affecting voting for president in 2004. Nonetheless, gay marriage was an important issue for a substantial number of voters. Probability simulations generated from estimates in Table 3 (reported in Table 5) illustrate the gay marriage issue had a notable effect on candidate choice in states where it was on the ballot. Table 5 illustrates that nationally, people ranking gay marriage as very important had a .57 estimated probability of supporting Bush (using estimates from Column 1, Table 3). People who ranked the issue as very important but did not reside in states where marriage ban campaigns primed the issue are predicted to be marginal Bush supporters (.53), whereas people who ranked the issue as very important who did live where marriage campaigns primed the issue are predicted to be solid (.69) Bush supporters, all else equal. We should stress that these probabilities are generated from simulations that set control variables at their mean/modal values (e.g., a white Protestant, female independent with mean levels of education, age and income, who believed Iraq, terrorism and the economy were each very important in evaluating the presidential candidates). The simulations illustrate that this distinct set of voters, living in states where marriage was on the ballot, may have been primed by gay marriage measures to move from marginal Bush supporters to likely Bush supporters.

\section{Discussion and Conclusion}

State-level institutions of direct democracy provide an institutional mechanism that can affect presidential elections. Our analysis demonstrates that ballot measures had agenda setting and priming effects in a presidential election. Our research extends on existing literature by demonstrating that priming is evident outside the laboratory, in the "real world" context of presidential elections. Existing studies have demonstrated priming effects on presidential evaluations, and our research demonstrates that priming also affects actual presidential vote intentions and reported vote choice. Where other evidence of priming affecting presidential evaluations identifies the mechanism for the prime as events exogenous to a campaign (e.g., scandal, war), we identify a mechanism (ballot measures) that campaigns or campaign surrogates may have more control over. It is also a mechanism that allows priming to occur when people are evaluating the candidates and voting.

Our results demonstrate that state same-sex marriage campaigns encouraged some voters, particularly people we assume were more likely to have predispositions about gay marriage that are latent (voters who were not born again Christians and those less attentive to politics), to be more likely to see gay 
TABle 3 Priming: 2004 Bush Support Among Respondents in Marriage Ban States who Ranked Gay Marriage as Very Important Issue (October Pre-Election and November Post-Election National Samples)

\begin{tabular}{|c|c|c|c|c|c|c|c|c|}
\hline & \multicolumn{2}{|c|}{$\begin{array}{l}\text { Intend to Vote } \\
\text { Bush (October) }\end{array}$} & \multicolumn{2}{|c|}{$\begin{array}{l}\text { Intend to Vote } \\
\text { Bush (October) }\end{array}$} & \multicolumn{2}{|c|}{$\begin{array}{l}\text { Intend to Vote } \\
\text { Bush (October) }\end{array}$} & \multicolumn{2}{|c|}{$\begin{array}{l}\text { Voted for Bush } \\
\text { (November) }\end{array}$} \\
\hline & Coef (sig) & $p$ & Coef (sig) & $p$ & Coef (sig) & $p$ & Coef (sig) & $p$ \\
\hline $\begin{array}{l}\text { Resides in Gay Marriage } \\
\text { Ban State }\end{array}$ & & & $-.21(.27)$ & .448 & $-.48(.25)$ & .056 & $-.95(.43)$ & .025 \\
\hline $\begin{array}{l}\text { Gay Marriage Issue Very } \\
\text { Important in Pres. Choice }\end{array}$ & $.38(.23)$ & .099 & $.15(.27)$ & .574 & $-.06(.26)$ & .820 & $-.45(.34)$ & .187 \\
\hline $\begin{array}{l}\text { Ban State* Gay Marriage } \\
\text { Issue Very Important }\end{array}$ & & & $.90(.44)$ & .039 & $1.08(.45)$ & .016 & $2.14(.84)$ & .011 \\
\hline $\begin{array}{l}\text { Terrorism Issue Very } \\
\text { Important in Pres. Choice }\end{array}$ & $2.14(.28)$ & .000 & $2.17(.28)$ & .000 & $2.15(.27)$ & .000 & $2.12(.41)$ & .000 \\
\hline $\begin{array}{l}\text { Iraq Issue Very Important } \\
\text { in Pres. Choice }\end{array}$ & $-.68(.24)$ & .004 & $-.70(.24)$ & .003 & $-.69(.25)$ & .005 & $-.87(.34)$ & .010 \\
\hline $\begin{array}{l}\text { Economy Very Important } \\
\text { in Pres. Choice }\end{array}$ & $-1.34(.25)$ & .000 & $-1.33(.24)$ & .000 & $-1.26(.26)$ & .000 & $-.97(.35)$ & .006 \\
\hline Republic & 61 & .000 & ) & 0 & & .0 & & .000 \\
\hline Demc & -2.50 & .000 & 2.5 & .000 & -2.6 & .000 & -2.3 & .000 \\
\hline Age & $-.001(.0$ & .793 & -.002 & .734 & -.001 & .985 & -.003 & .684 \\
\hline Male & $.25(.19)$ & .195 & $.25(.19)$ & .189 & $.24(.20)$ & .236 & $.48(.28)$ & .093 \\
\hline White & $.74(.31)$ & .016 & $.76(.32)$ & .018 & $.93(.34)$ & .006 & .66 & .082 \\
\hline Educat & $-.10(.06)$ & .087 & -.10 & .091 & -.09 & .165 & -.19 & .266 \\
\hline & & .02 & & .061 & $.14(.06)$ & .031 & $.12(.07)$ & .092 \\
\hline Protestant & $.31(.19)$ & .096 & $.31(.19)$ & .107 & & & & \\
\hline $\begin{array}{l}\text { Born again/ Evangelical/ } \\
\text { Fundamentalist Christian }\end{array}$ & & & & & $.97(.20)$ & .000 & $.84(.33)$ & .010 \\
\hline $\begin{array}{l}\text { Percent Vote for Bush in } \\
2000 \text { in Respondent's State }\end{array}$ & & & & & $5.41(1.09)$ & .000 & $5.00(2.10)$ & .017 \\
\hline Constant & $-1.33(.55)$ & .015 & $-1.28(.53)$ & .017 & $-4.34(.93)$ & .000 & $-3.54(1.38)$ & .010 \\
\hline Pseudo $\mathrm{R}^{2}$ & .52 & & .53 & & .55 & & .53 & \\
\hline Wald $\mathrm{Chi}^{2}$ & 499.75 & .000 & 605.13 & .000 & 599.44 & .000 & 160.17 & .000 \\
\hline Number & 951 & & 951 & & 963 & & 551 & \\
\hline
\end{tabular}

Note: The dependent variable is presidential vote choice in 2004. Unstandardized logistic regression coefficients with robust standard errors in parentheses. Standard errors adjusted by clustering cases by state. Statistical significance ( $\mathrm{p}$ values) are reported to the right of the coefficients are based on two-tailed tests.

marriage as an important issue. That we find this relationship toward the end of the campaign, but not early in the campaign, suggests strongly that the marriage measures were the mechanism that primed some voters to assess candidates in terms of the gay marriage issue. The marriage issue had a stronger effect on support for Bush in states where marriage measures were on the ballot. Some critical questions flow from our results that we must consider, but that we cannot answer definitively here. First, what type of issues, under what conditions, have the capacity to be used in conjunction with direct democracy to prime voters in the manner identified in this study? Second, does what we observe here represent a dangerous form of manipulative campaigning?

As far as the first question, gay marriage was a relatively low salience issue in 2004, with most people opposed to legal same-sex marriage (as opposed to civil unions). The two major candidates had opposing positions on the need for constitutional amendments prohibiting same-sex marriage. It would seem that some amount of issue valence, combined with candidates having distinct positions on the issue, would be necessary conditions for direct democracy to be used to prime an issue such that it works to the advantage of one candidate. These conditions may 
TABLE 4 Testing the Counterfactual: Bush Support Estimated with Residence in Marriage State, Interacted with Other Issues Respondents Ranked as Very Important. (October National Sample)

\begin{tabular}{|c|c|c|c|c|c|c|c|c|}
\hline \multirow[b]{2}{*}{ Resides in Marriage Ban State } & \multicolumn{8}{|c|}{ Dependent Variable $=$ Intend to Vote Bush } \\
\hline & $.17(.31)$ & .52 & $-.57(.40)$ & .14 & $.07(.46)$ & .87 & $-.44(.38)$ & .24 \\
\hline Ban State ${ }^{\star}$ Moral Values Very Important & $-.41(.29)$ & .15 & & & & & & \\
\hline Ban State ${ }^{\star}$ Iraq Very Important & & & $.56(.46)$ & .22 & & & & \\
\hline Ban State ${ }^{\star}$ Economy Very Important & & & & & $-.29(.58)$ & .62 & & \\
\hline Ban State ${ }^{\star}$ Terrorism Very Important & & & & & & & $.36(.50)$ & .47 \\
\hline Moral Values Very Important & $.96(.24)$ & .00 & & & & & & \\
\hline Gay Marriage Very Important & & & $.22(.23)$ & .34 & $.22(.23)$ & .34 & $.23(.23)$ & .32 \\
\hline Iraq Very Important & $-.78(.23)$ & .00 & $-.82(.29)$ & .00 & $-.66(.25)$ & .00 & $-.66(.24)$ & .00 \\
\hline Economy Very Important & $-1.42(.29)$ & .00 & $-1.29(.27)$ & .00 & $-1.21(.32)$ & .00 & $-1.27(.27)$ & .00 \\
\hline Terrorism Very Important & $2.00(.27)$ & .00 & $2.15(.29)$ & .00 & $2.10(.28)$ & .00 & $2.02(.31)$ & .00 \\
\hline Republican & $2.40(.23)$ & .00 & $2.57(.23)$ & .00 & $2.57(.23)$ & .00 & $2.58(.23)$ & .00 \\
\hline Democrat & $-2.66(.25)$ & .00 & $-2.61(.24)$ & .00 & $-2.64(.24)$ & .00 & $-2.63(.24)$ & .00 \\
\hline Age & $-.002(.006)$ & .69 & $.001(.006)$ & .89 & $.001(.006)$ & .89 & $.001(.006)$ & .90 \\
\hline Male & $.27(.18)$ & .13 & $.23(.20)$ & .24 & $.23(.20)$ & .24 & $.23(.20)$ & .24 \\
\hline White & $.97(.33)$ & .00 & $.89(.32)$ & .00 & $.90(.33)$ & .00 & $.88(.33)$ & .00 \\
\hline Education & $-.003(.07)$ & .96 & $-.08(.06)$ & .17 & $-.09(.06)$ & .15 & $-.09(.06)$ & .16 \\
\hline Income & $.13(.06)$ & .04 & $.13(.07)$ & .04 & $.14(.07)$ & .03 & $.14(.07)$ & .03 \\
\hline Born Again Christian & $.97(.21)$ & .00 & $.94(.20)$ & .00 & $.94(.20)$ & .00 & $.94(.20)$ & .00 \\
\hline Bush Pct Vote 2000 in state & $5.76(1.14)$ & .00 & $5.30(1.06)$ & .00 & $5.37(1.08)$ & .00 & $5.31(1.05)$ & .00 \\
\hline Constant & $-5.04(.97)$ & .00 & $-4.22(.98)$ & .00 & $-4.40(.99)$ & .00 & $-4.27(.94)$ & .00 \\
\hline Pseudo $\mathrm{R}^{2}$ & .55 & & .54 & & .54 & & .54 & \\
\hline Wald $\mathrm{Chi}^{2}$ & 522.63 & .00 & 588.83 & .00 & 564.41 & .00 & 566.27 & .00 \\
\hline Number & 978 & & 963 & & 963 & & 963 & \\
\hline
\end{tabular}

Note: The dependent variable is presidential vote intention / reported vote in 2004. Unstandardized logistic regression coefficients with robust standard errors in parentheses. Standard errors adjusted by clustering cases by state. Statistical significance ( $\mathrm{p}$ values) reported to the right of coefficients based on two-tailed tests.

not be too rare: presidential campaigns have proven to be adept at identifying (or crafting) such issues (e.g., race, immigration, criminal justice). There are at least two more conditions that may be necessary: (1) the issue must reach state ballots, and (2) it must coincide with a presidential contest. This is possible in any of the fifty states where advocates of an issue (or a candidate) have the political strength required to qualify a legislative referendum (or citizen initiative).

The second question is more perplexing. As Bartels (2003) notes, framing and priming effects in politics are often taken as evidence that elites manipulate the judgment of citizens, of the limits to citizen competence, and the general weakness of liberal models of democracy. The fact that direct democracy has the capacity to prime voters to assign greater emphasis to a specific issue when voting for president raises important normative issues. It suggests that, in addition to traditional mechanisms campaigns use to increase attention to an issue (e.g., campaign rhetoric, paid advertising), campaigns may have another tool to alter the set of potentially relevant considerations used by voters in specific states.

What of the normative implications of this? This may be seen as elite manipulation of voters and evidence of the ills of modern direct democracy. Or ballot measures may simply be another of many tools available to elites who compete to shape the public agenda. Our findings are consistent with research demonstrating limits to framing and priming effects and suggest that a limited pool of voters-those less attentive to a presidential campaign-are likely to be affected by priming via direct democracy. Large majorities of voters in our samples did report high levels of interest, and most reported having a partisan identification that predisposes them to vote for one of the major party candidates. This suggest that there limits to how much elites can use direct democracy to prime-or manipulate-voters. Yet in a very close election, a small proportion of marginal voters being affected by a direct democracy prime could be a nontrivial matter. 


\begin{tabular}{|c|c|c|c|}
\hline & $\begin{array}{c}\text { All Respondents } \\
\text { (Estimated from } \\
\text { Table 3, Column 1) }\end{array}$ & $\begin{array}{l}\text { Respondent lives in } \\
\text { state with no marriage } \\
\text { measure on ballot } \\
\text { (Estimated from }\end{array}$ & $\begin{array}{l}\text { Respondent lives in } \\
\text { state with marriage } \\
\text { measure on ballot } \\
\text { 3, Column2) }\end{array}$ \\
\hline $\begin{array}{l}\mathrm{R} \text { said gay marriage is } \\
\text { not very important when } \\
\text { evaluating presidential } \\
\text { candidates }\end{array}$ & $.48(.05)$ & $.49(.06)$ & $.44(.06)$ \\
\hline $\begin{array}{l}\mathrm{R} \text { said gay marriage } \\
\text { is very important when } \\
\text { evaluating presidential } \\
\text { candidates }\end{array}$ & $.57(.06)$ & $.53(.07)$ & $.69(.08)$ \\
\hline
\end{tabular}

Note: Predicted probabilities estimated with Clarify. Numbers in parentheses are standard errors. We hold age, income and education at their means. Gender is set at female, race/ethnicity at white (non-Hispanic) and religion at Protestant. All simulations estimated for independents. Believing terrorism, Iraq and economy "very important" in presidential vote set at modal categories (yes).

\section{Acknowledgments}

The authors thank Scott Keeter and the Pew Research Center for including our questions on their surveys.

Manuscript submitted 16 March 2007

Manuscript accepted for publication 1 December 2007

\section{References}

Ansolabehere, Stephen, Roy Behr, and Shanto Iyengar. 1993. The Media Game: American Politics in the Age of Television. New York: MacMillan.

Bartels, Larry. 2003. "Democracy with Attitudes." In Electoral Democracy, ed. Michael MacKuen and George Rabinowitz. Ann Arbor: University of Michigan Press, 48-82.

Berelson, Bernard, Paul Lazersfeld, and William McPhee. 1954. Voting. Chicago: University of Chicago Press.

$\rightarrow$ Bowler, Shaun, Steven Nicholson, and Gary Segura. 2006 "Earthquakes and Aftershocks: Direct Democracy and Partisan Change." American Journal of Political Science 50 (1): 146-59.

Brace, Paul, Kellie Sims-Butler, Kevin Arceneaux, and Martin Johnson. 2002. "Public Opinion in the American States: New Perspectives Using National Survey Data." American Journal of Political Science 46 (1): 173-89.

Campbell, Angus, Philip Converse, Warren Miller, and Donald Stokes. 1960. The American Voter. New York: Wiley.

Campbell, David E., and J. Quin Monson.N.d. "The Religion Card: Gay Marriage and the 2004 Presidential Election." Public Opinion Quarterly. Forthcoming.

Chavez, Lydia. 1998. The Color Bind: California's Battle to End Affirmative Action. Berkeley, CA: University of California Press.

Converse, Philip. 1962. "Information Flow and the Stability of Partisan Attitudes." Public Opinion Quarterly 26 (4): 578-99.
Downs, Anthony. 1972. "Up and Down with Ecology." The Public Interest 28 (Summer): 38-50.

$\rightarrow$ Druckman, James. 2001. "On the Limits of Framing Effects: Who Can Frame?" Journal of Politics 63 (4): 1041-66.

Druckman, James. 2004. "Political Preference Formation: Competition, Deliberation and the (Ir)relevance of Framing." American Political Science Review 98 (4): 671-86.

Druckman, James, Lawrence Jacobs, and Eric Ostermeier. 2004. "Candidate Strategies to Prime Issues and Images." Journal of Politics 64 (4): 1180-1202.

Finkel, Steven. 1993. "Reexamining the 'Minimal Effects' Model in Recent Presidential Elections." Journal of Politics 55 (2): $1-21$.

Geer, John. 1996. From Tea Leaves to Opinion Polls. New York: Columbia University Press.

Haider-Markel, Donald P., and Mark Joslyn. 2001. "Gun Policy, Opinion, Tragedy and Blame Attribution: The Conditional Influence of Issue Frames." Journal of Politics 63 (2): 520-43.

Haider-Markel, Donald P., and Kenneth J. Meier. 1996. "The Politics of Gay and Lesbian Rights: Expanding the Scope of the Conflict." Journal of Politics 58 (2): 332-49.

$\rightarrow$ Haider-Markel, Donald P., Alana Querze, and Kara Lindaman. 2007. "Lose, Win or Draw? A Reexamination of Direct Democracy and Minority Rights." Political Research Quarterly 60 (2): 304-14.

$\rightarrow$ Herek, Gregory. 2002. "Gender Gaps in Public Opinion about Lesbians and Gay Men." Public Opinion Quarterly 66 (1): 40-66.

$\rightarrow$ Hillygus, D. Sunshine, and Todd G. Shields. 2005. "Moral Issues and Voter Decision Making in the 2004 Presidential Election." PS: Political Science and Politics 38 (2): 201-09.

Holbrook, Thomas. 1996. Do Campaigns Matter? Thousand Oaks, CA: Sage Publications.

Iyengar, Shanto, and Donald Kinder. 1987. News that Matters: Television and American Opinion. Chicago: University of Chicago Press.

Jaccard, James, Robert Turrisi, and Choi Wan. 1990. "Interactive Effects in Multiple Regression.” Sage University Paper Series 
on Quantitative Applications in Social Sciences, Series \# 72. Newbury Park, CA: Sage.

Jamieson, Kathleen Hall. 1996. Packaging the Presidency: A History and Criticism of Presidential Advertising. Oxford: Oxford University Press.

Johnston, Richard, Andre Blais, Henry Brady, and Jean Crete. 1992. Letting the People Decide: Dynamics of a Canadian Election. Oxford: Oxford University Press.

Johnston, Richard, Michael Hagen, and Kathleen Hall Jamieson. 2001. The 2000 Presidential Election and the Foundations of Party Politics. Cambridge: Cambridge University Press.

Kinder, Donald, and Lynn Sanders. 1990. "Mimicking Political Debate with Survey Questions: The Case of White Opinion on Affirmative Action for Blacks." Social Cognition 8 (1): 73-103.

Krosnick, Jon A., and Laura Brannon. 1993. "The Impact of the gulf War on the Ingredients of Presidential Evaluations: Multidimensional Effects of Political Involvement." American Political Science Review 87 (4): 963-75.

Krosnick, Jon A., and Donald Kinder. 1990. "Altering the Foundations of Support for the President through Priming." American Political Science Review 84 (2): 497-512.

$\rightarrow$ Lanoue, David. 1992. “One That Made a Difference: Cognitive Consistency, Political Knowledge and the 1980 Presidential Debate." Public Opinion Quarterly 56 (2): 168-84.

$\rightarrow$ Lewis, Gregory B. 2005. "Same-Sex Marriage and the 2004 Presidential Election." PS: Political Science and Politics 38: 195-199.

Loftus, Jeni. 2001. “America's Liberalization in Attitudes toward Homosexuality, 1973-1998” American Sociological Review 66 (5): 762-82.

Lupia, Arthur. 1994. "Shortcuts versus Encyclopedias: Information and Voting Behavior in California Insurance Reform Elections." American Political Science Review 88 (1): 63-76.

McGuire, William J. 1968. "Personality and Susceptability to Social Influence." In E. Borgatta, W. Lambert (eds) Handbook of Personality Theory and Research. Chicago: Rand McNally, $1130-87$.
Mendelberg, Tali. 2001. The Race Card: Campaign Strategy, Implicit Messages and the Norm of Equality. Princeton, NJ: Princeton University Press.

$\rightarrow$ Mulligan, Kenneth. 2008. "The "Myth of Moral Values in the 2004 Presidential Election." PS: Political Science and Politics 41 (1): 109-14.

$\rightarrow$ Nicholson, Stephen. 2003. "The Political Environment and Ballot Proposition Awareness." American Journal of Political Science 47 (3): 403-10.

Nicholson, Stephen. 2005. Voting the Agenda: Candidates Elections and Ballot Propositions. Princeton, NJ: Princeton University Press.

Olson, Laura R., Wendy Cadge, and James T. Harrison 2006. "Religion and Public Opinion about Same Sex Marriage." Social Science Quarterly 87 (2): 340-60.

Popkin, Samuel. 1991. The Reasoning Voter: Communication and Persuasion in Presidential Campaigns. Chicago: University of Chicago Press.

Shaw, Darron. 1999. "The Effects of TV ads and Candidate Appearances on Statewide Presidential Votes 1988 - 96." American Political Science Review 93 (2): 345-61.

Sniderman, Paul, Richard A. Brody, and Philip E. Tetlock 1991. Reasoning and Choice: Explorations in Political Psychology. Cambridge: Cambridge University Press.

Zaller, John. 1992. The Nature and Origins of Mass Opinions. New York: Cambridge University Press.

Todd Donovan is professor of political science, Western Washington University, Bellingham, WA 98225. Caroline J. Tolbert is associate professor of political science, University of Iowa, Iowa City, IA 52242. Daniel A. Smith is associate professor of political science, University of Florida, Gainesville, FL 32611. 